\title{
Ranking Plant Species for Stabilizing SandDune to Combat Desertification by Multi-Criteria Decision Making Methods of ELECTRE and LINEAR Assignment
}

\author{
Azam Abdolazimi ${ }^{1}$, Majid Montazeri ${ }^{2} \&$ Mehdi Momeni ${ }^{1}$ \\ ${ }^{1}$ Faculty of Humanities, Najafabad Branch, Islamic Azad University, Najafabad, Isfahan, Iran \\ ${ }^{2}$ Assistant Professor of Climatology, University of Isfahan, Isfahan, Iran \\ Correspondence: Azam Abdolazimi, Faculty of Humanities, Najafabad Branch, Islamic Azad University, \\ Najafabad, Isfahan, Iran. E-mail: azamabdolazimi@yahoo.com; saba221azam@gmail.com
}

\author{
Received: September 22, 2014 Accepted: October 11, 2014 Online Published: December 2, 2014 \\ doi:10.5539/ass.v11n1p119 URL: http://dx.doi.org/10.5539/ass.v11n1p119
}

\begin{abstract}
In this study, it is attempted to rank plant species in order to stabilize sand by the application of ELECTRE, and Liner assignment methods in Rig, Sirjan, Iran. The results suggest that in linear assignment method among 7 plant species, milk vetch species is in the first ranking with one score, and is the best species to stabilize sand in the studied area and the Camel's thorn species lies at the bottom of the ranking chart and can't be suitable for sand stabilization. Artichoke, Espand, Glasswort, Sagebrush and Charkha lie in the next rankings respectively by their importance. In ELECTRE method, among 7 plant species studied in this research, the milk vetch species with four dominances and one defeat with 3 scores is in the first ranking and the Camel's thorn and Artichoke species with five defeats and no dominance with $(-5)$ score lie at the bottom of the ranking. Glasswort, Charkha, Espand and Sagebrush with $(1,1,1,3)$ dominances and $(4,4,4,2)$ defeats with $(-3,-3,-3,1)$ scores respectively lie in the next ranks. It should be noticed that Artichoke, Camel's thorn, Glasswort, Charkha and Espand species must be omitted because the number of their dominances were less than the number of their defeats. The results of the linear method were more compatible with reality and were more accurate and precise.
\end{abstract}

Keywords: plant species, SandDune, stabilization, linear assignment algorithm, linear assignment method, ELECTRE method

\section{Introduction}

Wind erosion is the most important destructive factor during the Quaternary in the desert areas in Iran. Due to a decrease in vegetation density, winds cause damage and carry materials and create ripples and roughness in sand so that at present, the surface of 30 million hectares are affected by wind (Ahmadi \& FeizNia, 1999).

Ample plains, poverty or lack of vegetation, the abundance of fine particles, and loose or detached grains are all factors that provide the requirements for wind morphogenesis generation operations in the interior plains (Alaaee \& Taleghani, 2005). Wind geomorphology provides a rich and extensive body of research for studying wind processes and landforms in the surface of the earth. Sand carriage by wind processes is done under the influence of non-linear, complex relationships.

The development of sand roughness and ripples is affected by self-regulation phenomenon dominating the perspective system. Since plants are more stable and durable than moisture, so they have a more effective role in regulating the movement of material by wind. The most important role of vegetation in reducing wind erosion is causing roughness and ripples so that the speed of wind at the surface of the earth is reduced (Refahi, 2009).

Refahi stated that the height, shape and density of vegetation play a significant role in the rate and degree of wind erosion (Quoted by Marshal, 1971; Vesven \& Naninga, 1986). The type and density of vegetation leads to sediments' dynamics in the system, so that vegetation reduces sediment transference and carriage and limits sediment supply (Lancaster \& Baas, 1998).

When the development of vegetation cover is under the influence of the burial of sediments and erosion, different plant species have different strengths and show different resistance to the burial of eolians and can influence the pile or dune in the form of selective carriage and burial (Van der Stoel et al., 2002). 
Vali and Ghazavi (2006) studied the reaction or response of different types and species of vegetation to environmental tensions and stresses and stated that environmental tensions are mostly salt, dryness, and burial tensions. Plants cope with salt tension by creating plant dunes and piles to modulate environmental conditions. Plants cope with shortage of water or dehydration tensions by decreasing evaporation- transpiration surface of aerial organs and they cope with burial tensions by creating height difference with the base surface of the area, which leads to special uneven elevations and roughness and ripples called Nebkha. The important point in the deposition of eolian sediment process is vegetation cover condition. Different factors such as ecological tolerance of different types of plant species have an important role in the deposition of sediments so that the deposition potential varies in different species (Dougill \& Thomas, 2002).

Poorkhosravani et al. studied nebkhas of Tamarisk shrubs species in Kheir Abad area in Sirjan and reported that the element of the plant canopy has the most impact on the deposition of eolian sediments (Poorkhosravani, 2010). In analyzing the relationships between the elements of canopy vegetationcoverage density and the degree of deposition and the complexity in the relationships, Danin explained the relationships using the diversity of canopy density and their performance in trapping wind sediments and the formation of different shapes of nebkha roughness and ripples and stated that different species have different performances against eolian processes according to the ecological nature of their canopy coverage. Moderately dense canopy species perform well in trapping sediments and mass dense species have acted as an impermeable windbreak. Both groups have the capability to make nebkha; however, in mass dense canopy coverage group, in addition to forming nebkha around the ring, a ditch is formed at the sides of the gully because of the increase in lateral flow of the nebkha. In general, the results of the research show that differences in plant ecology affect the manner and extent of eolian sediment deposition so that nebkh as from Blanaitessp species grow faster than nebkhas from Acacia species although they are in the same environment (Danin, 1996).

Regarding multi-criteria decision making methods, Limon and Martinez (2006) used Multi-Attribute Utility Theory (MAUT) for optimal allocation of water for agriculture in the north of Spain (Limon, 2006). Ahmadi et al. (2002) ranked different projects for filtration of agricultural water for its reuse using multi-criteria decision making methods (Ahamdi et al., 2002).

Anand Raj and Kumar (1996) used ELECTER method for ranking alternatives for the management of the river basin (Anand, 1996). The present study aims at ranking plant species to stabilize sand dune using ELECTRE and Linear assignment methods.

\section{Materials and Methods}

The studied area called Rig in Sirjan or Eshagh Abad, and Kazem Abad pasturelands with coordinates 55 degree and 36 minutes to 55 degrees and 45 minutes east longitude and 29 degrees and 33 minutes to and to 29 degrees and 44 minutes north latitude are located in the north Sirjan city (Airport Area). The highest point in the study area is 2050 meters and the lowest point with an altitude of 1855 meters is from the sea level. The mean elevation of the watershed is 1980 meters above the sea level.

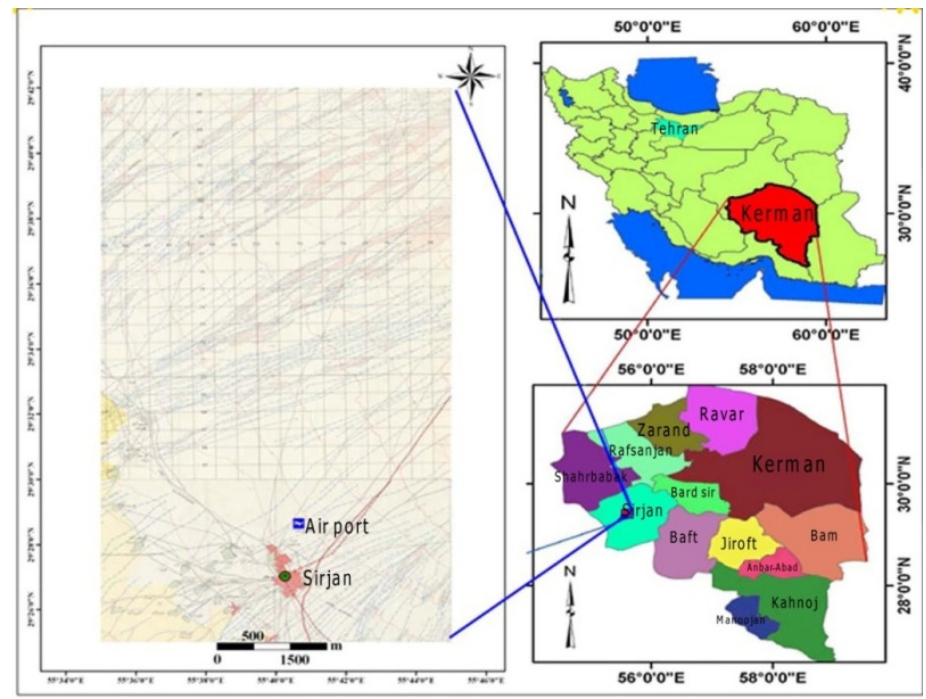

Figure 1. Mathematical figure and position of the studied area 
In this study, field and library research are used so that first field research is used to measure physical parameters such as plant height, canopy diameter, canopy surface. Then, in the next step, after obtaining these parameters, species were ranked using ELECTRE and Linear assignment methods. The two methods were compared in terms of accuracy.

\section{Theoretical Foundations of ELECTRE and Linear Assignment Methods}

In recent decades, multi-criteria decision making models (MCDM) have attracted the attention of many researchers for complex decisions. These models are divided into two main categories: Multi-objective decision making (MODM) and Multi-attribute decision making (MADM) models so that multi-attribute models are used for selecting the best option. Assessment models for a MADM divided into compensatory and non-compensatory models (Saaty, 1986).

Non-compensatory model includes models which often do not require information from DM and lead to a concrete answer. In compensatory model, the exchange between attributes is allowed, i.e. for example the shortcoming or weakness of an attribute is compensated by score of another attribute.

ELECTRE method is one of the available methods in compensatory models. In this method, all alternatives or options are assessed using "non-ranked" comparisons. All the stages of performing this method are based on a coordinated set and a non-coordinated set; therefore, it is known as "Analysis of coordination".

The ELECTER method was provided by Banayoun and then developed by Van Delft, Nijkamp, Roy, and other colleagues. In ELECTER method, the concept of dominance is implicitly used. In this method, options or alternatives are compared pairwise and the dominant and weak options are identified and then the weak or defeated options are removed (Roy, 1991).

Linear assignment method is one of multi-criteria decision-making methods, which helps decision makers to select the best choice by combining quantitative and qualitative attributes and the appropriate weighting of each criterion based on its importance. In this method, the assumed alternatives or options of a given problem are ranked based on their scores of each existing attribute and final ranking of options will be determined through Linear Compensatory Process. The position of these two models among multi-criteria decision-making methods is shown in Figure 2. The resolution process is done in a way that there is no need to descale qualitative and quantitative attributes.

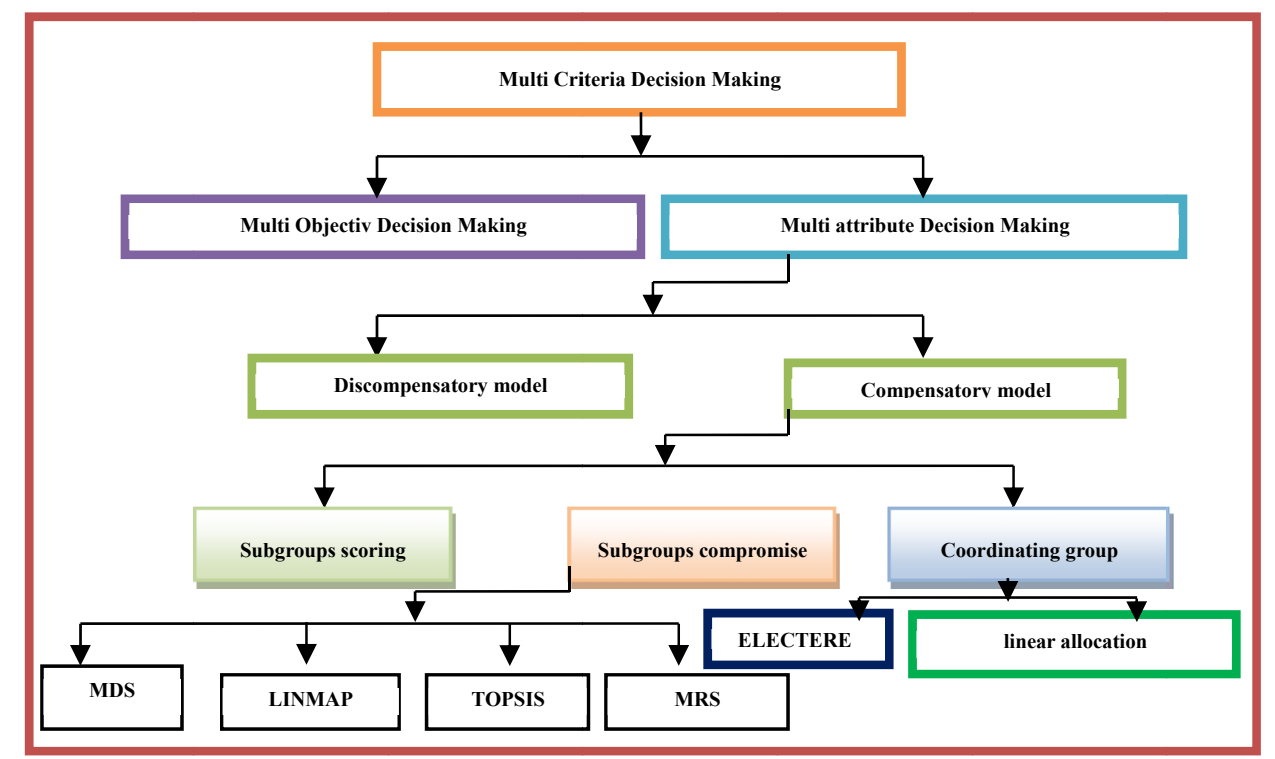

Figure 2. Position of linear assignment and ELECTER among multi-criteria decision-making methods

\section{The stages of problem solving by ELECTRE and Linear assignment methods}

\section{A-Stages of problem solving by linear assignment method}

\section{1-Forming decision matrix}

First, the decision matrix is formed given the quantitative data obtained from the attributes in each region. 


\section{2- Ranking alternatives on the basis of existing attributes}

At this stage, the regions are ranked based on the rank given to them by the attributes.

3- In the third stage, matrix QG is obtained by specifying the weights of attributes (W). Each element of the QG matrix is equal to: Equation (1)

$$
q / i t=\sum_{j=1}^{n} \pi i t j \cdot \mathrm{wj}
$$

If option $i$ is in the ranking $t$ in the attribute $j$, then $\pi i t j=1$.

4-The following assignment problem with the variables zero-one hit is solved in order to determine the final priorities of alternatives.

$$
\begin{gathered}
\text { Equation (2) } \max : \sum_{i=1}^{m} \sum_{k=1}^{m} \gamma_{i k} . h_{i k} \\
\text { s.t }: \sum_{k=1}^{m} h_{i k}=1 \quad ; \quad i=1,2, \ldots, m \\
\text { Equation (3) }: \quad \sum_{i=1}^{m} h_{i k}=1 ; k=1,2, \ldots, m \\
h_{i k}\left\{\begin{array}{l}
=1 \\
=0
\end{array}\right.
\end{gathered}
$$

5-Ranking alternatives

The final step is to rank the options or alternatives.

\section{B-The stages of problem solving be ELECTRE method}

\section{1-Forming decision matrix}

According to the criteria and the number of choices and options, and the evaluation of all options for different criteria, decision matrix is formed as follows:

$$
X=\left[\begin{array}{ccc}
x_{11} & \ldots & x_{1 n} \\
\vdots & \ldots & \ldots \\
x_{1 m} & \ldots & x_{m n}
\end{array}\right]
$$

where $\mathrm{Xij}$ is the performance or functioning of option $\mathrm{i}$ th $(\mathrm{i}=1,2, \ldots \ldots, \mathrm{m})$ in relation to criteria $\mathrm{jth}(\mathrm{j}=$ $1,2,3, \ldots \ldots, \mathrm{n})$.

\section{2-Descaling decision matrix}

At this stage, it is tried to convert criteria with different dimensions or aspects to dimensionless criteria and the matrix $\mathrm{R}$ is defined as follows. There are various methods for making criteria dimensionless, but in ELECTRE method in the following equation is commonly used (Tille, 2003). Equation (4):

$$
R=\left[\begin{array}{ccc}
r_{11} & \ldots & r_{1 n} \\
\vdots & \ldots & \ldots \\
r_{m 1} & \ldots & r_{m n}
\end{array}\right] r_{i j}=\frac{x_{i j}}{\sqrt{\sum_{i=1}^{m} x_{i j}^{2}}}
$$

\section{3-Determining the matrix of the weights of criteria}

$$
W=\left[\begin{array}{ccc}
w_{1} & \ldots & 0 \\
\vdots & w_{2} & \ldots \\
0 & \ldots & w_{n}
\end{array}\right]
$$

As it can be seen, the matrix $\mathrm{W}$ is a diagonal matrix, in which only the elements on its main diagonal are not zero and the value of these elements is equal to the importance coefficient of the corresponding vector.

\section{4-Determining the weighted normalized decision matrix}

Weighted decision matrix is obtained from descaled decision matrix multiplied by the matrix of the weights of criteria.

$$
V=R \times W=\left[\begin{array}{ccc}
v_{11} & \ldots & v_{1 n} \\
\vdots & \ldots & \ldots \\
v_{m 1} & \ldots & v_{m n}
\end{array}\right]
$$




\section{5-Establishing a set of agreement and disagreement criteria}

For each pair of options of $\mathrm{e}$, and $\mathrm{k}(\mathrm{k}, \mathrm{e}=1,2, \ldots ., \mathrm{m}, \mathrm{k} \# \mathrm{e})$, the set of criteria $\mathrm{J}=(1,2, \ldots . ., \mathrm{m})$ is divided into two agreement and disagreement or opposing categories or sub-set: The agreement set (SKe) is a set of criteria in which option $\mathrm{K}$ is preferred to option e, and its complementary set is the disagreement set (IKe), Mathematically, Equation (5) and (6):

$$
\begin{array}{r}
S_{k e}=\left\{j \mid v_{k j} \geq v_{e j}\right\} \\
I_{k e}=\left\{j \mid v_{k j} \prec v_{e j}\right\}
\end{array}
$$

\section{6-Forming the agreement matrix}

In order to form the agreement matrix, its elements of the agreement which are called coopration criteria should be calculated. The agreement criterion is obtained by the sum of the weights of criteria which are in agreement in total. Therefore, this cooperation criterion is between the options $\mathrm{k}$ and e is equal to Equation 7 (Roy, 1999, 49-73).

$$
c_{k e}=\frac{\sum_{j \in s_{k e}} W_{j}}{\sum_{j=1} W_{j}}
$$

For the sum of normalized weights $\sum_{j \in 1} W_{j}$ is equal to 1; therefore, Equation (8):

$$
c_{k e}=\sum_{j \in s_{k e}} W_{j}
$$

The cooperation criteria indicate the degree of the predominance or preference of option $\mathrm{k}$ to option $\mathrm{e}$ and its value varies from 0 to 1 . By calculating cooperation criteria for all options, the agreement matrix which is an $\mathrm{m}$ * $\mathrm{m}$ matrix is defined as follows, in general, this matrix is not symmetric:

$$
C=\left[\begin{array}{cccc}
- & c_{12} & \ldots & c_{1 m} \\
c_{21} & - & \ldots & c_{2 m} \\
\vdots & \vdots & - & \vdots \\
c_{m 1} & \ldots & c_{m(m-1)} & -
\end{array}\right]
$$

\section{7-Determining the disagreement matrix}

Disagreement Criterion (opposite) is defined as follows (Roy, 1991, 49-73). Equation (9):

$$
d_{k e}=\frac{\max _{j \in I_{k e}}\left|v_{k j}-v_{e j}\right|}{\max _{j \in J}\left|v_{k j}-v_{e j}\right|}
$$

Disagreement criterion (opposite) varies from zero to one. By calculating disagreement criterion for all pair of options, the disagreement matrix which is an $\mathrm{m} * \mathrm{~m}$ matrix is defined as follows, in general, this matrix is not symmetric:

$$
D=\left[\begin{array}{cccc}
- & d_{12} & \ldots & d_{1 m} \\
d_{21} & - & \ldots & d_{2 m} \\
\vdots & \vdots & - & \vdots \\
d_{m 1} & \ldots & d_{m(m-1)} & -
\end{array}\right]
$$

It should be noted that the information and data contained in the agreement matrix varies significantly from the data in the disagreement matrix and there are considerable differences between them. In fact, these data are complementary. The differences between weights are achieved through agreement matrix, while the differences between determined values are obtained by the disagreement matrix.

\section{8- Forming agreement dominance matrix}

In the sixth stage, computing the criterion of agreement $C_{\mathrm{ke}}$ was expressed. At this stage, a certain amount is determined for agreement criterion which is called agreement threshold and is shown by $\bar{c}$. If $\mathrm{C}_{\mathrm{ke}}$ is larger than 
$\bar{c}$, the superiority or dominance of alternative $\mathrm{k}$ to alternative $\mathrm{e}$ is acceptable, otherwise the option $\mathrm{k}$ is not superior to the option e. The value of agreement threshold is calculated by the following equation (Roy, 1991, 49-73). Equation (10):

$$
\bar{c}=\sum_{\substack{k=1 \\ k \neq e}}^{m} \sum_{\substack{e=1 \\ e \neq k}}^{m} \frac{c_{k e}}{m(m-1)}
$$

Agreement dominance matrix (F) is formed according to the value of agreement threshold whose members are determined by the following equation (Vami, 1992). Equation (11):

$$
f_{k e}= \begin{cases}0 & c_{k e} \geq \bar{c} \\ 1 & c_{k e}<\bar{c}\end{cases}
$$

\section{9-Forming disagreement dominance matrix}

Disagreement dominance matrix $(\mathrm{G})$ is formed like agreement dominance matrix. For this purpose, first the disagreement threshold $\bar{d}$ should be expressed by decision makers which can be, e.g., the mean of disagreement (opposition) criteria (Roy, 1991, pp. 49-73). Equation (12):

$$
\bar{d}=\sum_{\substack{k=1 \\ k \neq e}}^{m} \sum_{e=1}^{m} \frac{d_{k e}}{m(m-1)}
$$

As mentioned in the seventh stage, the less the disagreement criterion $\left(\mathrm{d}_{\mathrm{ke}}\right)$ the better, because the disagreement degree indicates the superiority of option $\mathrm{k}$ to option e. If $\mathrm{D}_{\mathrm{ke}}$ is larger than $\bar{d}$, the degree of disagreement is high and not negligible; as a result, the matrix of the elements of disagreement dominance $(\mathrm{G})$ is calculated as follows (Roy, 1991, 49-73). Equation (13):

$$
g_{k e}= \begin{cases}0 & d_{k e} \geq \bar{d} \\ 1 & d_{k e}<\bar{d}\end{cases}
$$

Each member of the matrix $(\mathrm{G})$ indicates the dominance relationship between alternatives.

\section{0- Forming the final dominance matrix}

The final dominance matrix $\mathrm{H}$ is obtained by the multiplication of every elements of agreement dominance matrix F by on the disagreement dominance matrix G (Roy, 1991, 49-73). Equation (14):

$$
h_{k e}=f_{k e} \cdot g_{k e}
$$

\section{1-Removing the options with less satisfaction and selecting the best option}

The final dominance matrix $\mathrm{H}$ expresses the little or trivial preferences of options. For example, if the value of $\mathrm{h}_{\mathrm{ke}}$ is equal to 1 , it means that the superiority or dominance of option $\mathrm{k}$ to option e is acceptable in both agreement and disagreement situations, that is, its superiority is greater than agreement threshold and its disagreement or weakness is lower than the disagreement threshold, but the option $\mathrm{k}$ has still the chance to be dominated by other options. The option should be selected which has more dominance rather being defeated and therefore the options can be ranked. For determining the significance coefficient of criteria in relation to each other, first criteria are compared pairwise according to the method recommended by Saaty.

Table 1. Weighing factors based on preferences in the form of pairwise comparisons

\begin{tabular}{cc}
\hline Numerical Number & Preferences (oral judgments) \\
9 & Extremely preferred \\
7 & Very strongly preferred \\
5 & Strongly preferred \\
3 & Moderately referred \\
1 & Equally preferred \\
$2,4,6,8$ & Preferences between strong intervals \\
\hline
\end{tabular}

After the formation of pair-wise comparison matrix, the relative weight of criteria can be calculated. There are different methods to calculate the relative weights based on pairwise comparison matrix. The most important ones are "least square method, the least square logarithmic method, specific vector method and the approximate 
method. Among these methods, specific vector method is more accurate than others. In this method, $\mathrm{w}_{\mathrm{i}}$ is defined in such a way that equation 12 is established. Equation (15):

$$
\mathrm{A} \times \mathrm{W}=\lambda \max \mathrm{W}
$$

where $\lambda$ and $\mathrm{W}$ are respectively the specific values and specific vector of pair-wise comparison matrix (A). While the dimensions of the matrix are larger, calculating these values are time-consuming. Therefore, to calculate the value of $\lambda$, the values of terminal matrix $\lambda \mathrm{IA}$ is set equal to zero and by placing the largest $\lambda$ value in equation (13), the values of $\mathrm{w}_{\mathrm{i}}$ are obtained (Saaty, 2001, p. 315). Equation (16):

$$
\mathrm{A}-\lambda_{\max } \mathrm{I}=0
$$

\section{Discussion}

Systematic approach to the geography as a dispersion science made geography dependent to mathematics more than ever before (Shokooee, 1998). In general, the model is a schematic but accurate description of the system that apparently is consistent with its past behavior. Therefore, there is hope that this model can be used to predict the future behavior of the system (Tavakoli et. al., 2005, p. 29). Decision-making models and optimization of them has always been the focus of attention of mathematicians and industry professionals since the industrial movement in the world, and especially since World War II but their base has been having an assessment criterion (Asayesh \& Estelaji, 2003).

In recent decades, the attention of researchers is shifting to multi-criteria decision making models for complex decision makings. In these models, instead of using a desirable criterion a number of assessment criteria are used. Nowadays, prioritizing and selecting alternatives and appropriate substitutes among various factors and making a decision among them are of great important in environmental planning and management (Kohansal et. al., 2008). In other words, in order to achieve better results, using appropriate methods which have the ability to combine multiple attributes seem necessary so that it will become possible to make appropriate preparations and logistics for environmental planning and management.

The results from the problem solving of ranking plant species to stabilize sand dune are shown in the form of matrixes in Tables 2 to 17 . As it can be seen in matrixes 8 , and 17, the best species is milk vetch. This result is in consistency with the features of this species shown in Table 2 and 8 .

Matrixes of problem solving in linear assignment method.

Table 2. Decision matrix (X)

\begin{tabular}{cccccc}
\hline Parameters & $\begin{array}{c}\text { Compatibility } \\
\text { rate with } \\
\text { environment }\end{array}$ & $\begin{array}{c}\text { Plant height } \\
(\mathrm{cm})\end{array}$ & $\begin{array}{c}\text { Density in } \\
\text { hectare }\end{array}$ & $\begin{array}{c}\text { Canopy } \\
\text { Diameter }(\mathrm{cm})\end{array}$ & $\begin{array}{c}\text { Canopy Surface } \\
(\%)\end{array}$ \\
\hline Sagebrush & 8 & 52 & 150 & 67 & 35 \\
Artichoke & 4 & 35 & 65 & 32 & 18 \\
Charkha & 7 & 31 & 120 & 30 & $32 / 5$ \\
Milk vetch & 9 & 75 & 180 & 85 & $39 / 4$ \\
Espand & 5 & 50 & 105 & 65 & 21 \\
Camel's thorn & 3 & 30 & 55 & 40 & 20 \\
Glasswort & 6 & 40 & 110 & 45 & 25 \\
\hline
\end{tabular}

Table 3. Alternatives' ranking matrix based on attributes

\begin{tabular}{cccccc}
\hline Parameters & $\begin{array}{c}\text { Compatibility } \\
\text { rate with the } \\
\text { environment }\end{array}$ & $\begin{array}{c}\text { Plant height } \\
(\mathrm{cm})\end{array}$ & $\begin{array}{c}\text { Density in } \\
\text { hectare }\end{array}$ & $\begin{array}{c}\text { Canopy } \\
\text { Diameter }(\mathrm{cm})\end{array}$ & $\begin{array}{c}\text { Canopy Surface } \\
(\%)\end{array}$ \\
\hline Species & Milk vetch & Milk vetch & Milk vetch & Milk vetch & Milk vetch \\
Artichoke & Sagebrush & Sagebrush & Sagebrush & Sagebrush & Sagebrush \\
Charkha & Charkha & Espand & Charkha & Espand & Charkha \\
Milk vetch & Glasswort & Glasswort & Glasswort & Glasswort & Glasswort \\
Espand & Espand & Aetichoke & Espand & Camel's thorn & Espand \\
Camel's thorn & Aetichoke & Charkha & Aetichoke & Aetichoke & Camel's thorn \\
Glasswort & Camel's thorn & Camel's thorn & Camel's thorn & Charkha & Aetichoke \\
\hline
\end{tabular}


Table 4. Matrix of the number of getting a rank in alternatives

\begin{tabular}{cccccccc}
\hline Regions & First rank & Second rank & Third rank & Fourth rank & Fifth rank & Sixth rank & Seventh rank \\
\hline Sagebrush & 0 & 5 & 0 & 0 & 0 & 0 & 0 \\
Artichoke & 0 & 0 & 0 & 0 & 2 & 2 & 1 \\
Charkha & 0 & 0 & 3 & 0 & 0 & 1 & 1 \\
Milk vetch & 5 & 0 & 0 & 0 & 0 & 0 & 0 \\
Espand & 0 & 0 & 2 & 0 & 3 & 0 & 0 \\
Camel's thorn & 0 & 0 & 0 & 0 & 1 & 1 & 3 \\
Glasswort & 0 & 0 & 0 & 0 & 5 & 0 & 0 \\
\hline
\end{tabular}

Table 5. Pairwise comparisons matrix of different criteria

\begin{tabular}{ccccccc}
\hline Parameters & $\begin{array}{c}\text { Compatibility rate } \\
\text { with the environment }\end{array}$ & $\begin{array}{c}\text { Plant height } \\
(\mathrm{cm})\end{array}$ & $\begin{array}{c}\text { Density in } \\
\text { hectare }\end{array}$ & $\begin{array}{c}\text { Canopy } \\
\text { Diameter }(\mathrm{cm})\end{array}$ & $\begin{array}{c}\text { Canopy } \\
\text { Surface }(\%)\end{array}$ & $\begin{array}{c}\text { Weight } \\
\text { vector }\end{array}$ \\
\hline Compatibility rate & 1 & 3 & 5 & 7 & 5 & $0 / 5028$ \\
Plant height & $0 / 33$ & 1 & 3 & 5 & 7 & $0 / 2602$ \\
Density in hectare & $0 / 2$ & $0 / 33$ & 1 & 3 & 5 & $0 / 1344$ \\
Canopy Diameter & $0 / 14$ & $0 / 2$ & $0 / 33$ & 1 & 3 & $0 / 0678$ \\
Canopy Surface & $0 / 11$ & $0 / 14$ & $0 / 2$ & $0 / 33$ & 1 & $0 / 0348$ \\
Sum & $1 / 78$ & $4 / 67$ & $9 / 53$ & $16 / 33$ & 25 & 1 \\
\hline
\end{tabular}

Table 6. The matrix of the weight of the number of alternatives' rankings

\begin{tabular}{cccccccc}
\hline Regions & First rank & Second rank & Third rank & Fourth rank & Fifth rank & Sixth rank & Seventh rank \\
\hline Sagebrush & 0 & 1 & 0 & 0 & 0 & 0 & 0 \\
Artichoke & 0 & 0 & 0 & 0 & $0 / 26$ & $0 / 704948$ & $0 / 0348$ \\
Charkha & 0 & 0 & $0 / 671991$ & 0 & 0 & $0 / 26$ & $0 / 067$ \\
Milk vetch & 1 & 0 & 0 & 0 & 0 & 0 & 0 \\
Espand & 0 & 0 & $0 / 328009$ & 0 & $0 / 671991$ & 0 & 0 \\
Camel's thorn & 0 & 0 & 0 & 0 & $0 / 067$ & $0 / 034$ & $0 / 897402$ \\
Glasswort & 0 & 0 & 0 & 1 & 0 & 0 & 0 \\
\hline
\end{tabular}

Table 7. Alternatives' scoring table

\begin{tabular}{|c|c|c|c|c|c|c|c|}
\hline$\underbrace{\text { Scores }}_{\text {Species }}$ & & & & & & & \\
\hline Sagebrush & 0 & 1 & 0 & 0 & 0 & 0 & 0 \\
\hline Artichoke & 0 & 0 & 0 & 0 & 0 & 0 & 1 \\
\hline Charkha & 0 & 0 & 1 & 0 & 0 & 0 & 0 \\
\hline Milk vetch & 1 & 0 & 0 & 0 & 0 & 0 & 0 \\
\hline Espand & 0 & 0 & 0 & 0 & 1 & 0 & 0 \\
\hline Camel's thorn & 0 & 0 & 0 & 0 & 0 & 1 & 0 \\
\hline Glasswort & 0 & 0 & 0 & 1 & 0 & 0 & 0 \\
\hline
\end{tabular}

Table 8. Alternatives' ranking

\begin{tabular}{cccccccc}
\hline Species & Sagebrush & Artichoke & Charkha & Milk vetch & Espand & Camel's thorn & Glasswort \\
\hline Ranks & Second & Seventh & Third & First & Fifth & Sixth & Fourth \\
\hline
\end{tabular}

Table 9. Descaled decision matrix (R)

\begin{tabular}{cccccc}
\hline Species & $\begin{array}{c}\text { Compatibility rate with } \\
\text { environment }\end{array}$ & $\begin{array}{c}\text { Plant height } \\
(\mathrm{cm})\end{array}$ & $\begin{array}{c}\text { Density in } \\
\text { hectare }\end{array}$ & $\begin{array}{c}\text { Canopy Diameter } \\
(\mathrm{cm})\end{array}$ & $\begin{array}{c}\text { Canopy Surface } \\
(\%)\end{array}$ \\
\hline Sagebrush & $0 / 4781$ & $0 / 4175$ & $0 / 4751$ & $0 / 4571$ & $0 / 4667$ \\
Artichoke & $0 / 2390$ & $0 / 2810$ & $0 / 2059$ & $0 / 2183$ & $0 / 2400$ \\
Charkha & $0 / 4183$ & $0 / 2489$ & $0 / 3801$ & $0 / 2048$ & $0 / 4334$ \\
Milk vetch & $0 / 5379$ & $0 / 6021$ & $0 / 5701$ & $0 / 5799$ & $0 / 5254$ \\
Espand & $0 / 2988$ & $0 / 4014$ & $0 / 3326$ & $0 / 4434$ & $0 / 2800$ \\
Camel's thorn & $0 / 1793$ & $0 / 2408$ & $0 / 1742$ & $0 / 2729$ & $0 / 2667$ \\
Glasswort & $0 / 3586$ & $0 / 3211$ & $0 / 3484$ & $0 / 3070$ & $0 / 3334$ \\
\hline
\end{tabular}


Table 10. Pairwise comparisons matrix of different criteria (S)

\begin{tabular}{ccccccc}
\hline Parameters & $\begin{array}{c}\text { Compatibility } \\
\text { rate with } \\
\text { environment }\end{array}$ & $\begin{array}{c}\text { Plant } \\
\text { height } \\
(\mathrm{cm})\end{array}$ & $\begin{array}{c}\text { Density in } \\
\text { hectare }\end{array}$ & $\begin{array}{c}\text { Canopy } \\
\text { Diameter }(\mathrm{cm})\end{array}$ & $\begin{array}{c}\text { Canopy } \\
\text { Surface } \\
(\%)\end{array}$ & $\begin{array}{c}\text { Weight } \\
\text { vector }\end{array}$ \\
\hline Compatibility rate & 1 & 3 & 5 & 7 & 5 & $0 / 5028$ \\
Plant height & $0 / 33$ & 1 & 3 & 5 & 7 & $0 / 2602$ \\
Density in hectare & $0 / 2$ & $0 / 33$ & 1 & 1 & 5 & $0 / 1344$ \\
Canopy Diameter $(\mathrm{cm})$ & $0 / 14$ & $0 / 2$ & $0 / 33$ & $0 / 33$ & 3 & $0 / 0678$ \\
Canopy Surface & $0 / 11$ & $0 / 14$ & $0 / 2$ & $16 / 33$ & 1 & $0 / 0348$ \\
Sum & $1 / 78$ & $4 / 67$ & $9 / 53$ & & 25 & 1 \\
\hline
\end{tabular}

Table 11. Normalized weighted decision matrix (V)

\begin{tabular}{cccccc}
\hline Species & $\begin{array}{c}\text { Compatibility rate } \\
\text { with environment }\end{array}$ & $\begin{array}{c}\text { Plant height } \\
(\mathrm{cm})\end{array}$ & $\begin{array}{c}\text { Density in } \\
\text { hectare }\end{array}$ & $\begin{array}{c}\text { Canopy Diameter } \\
(\mathrm{cm})\end{array}$ & $\begin{array}{c}\text { Canopy Surface } \\
(\%)\end{array}$ \\
\hline Sagebrush & $0 / 2404$ & $0 / 1086$ & $0 / 0638$ & $0 / 0310$ & $0 / 0163$ \\
Artichoke & $0 / 1202$ & $0 / 0731$ & $0 / 0277$ & $0 / 0148$ & $0 / 0084$ \\
Charkha & $0 / 2103$ & $0 / 0648$ & $0 / 0511$ & $0 / 0139$ & $0 / 0151$ \\
Milk vetch & $0 / 2704$ & $0 / 1567$ & $0 / 0766$ & $0 / 0393$ & $0 / 0183$ \\
Espand & $0 / 1502$ & $0 / 1045$ & $0 / 0447$ & $0 / 0301$ & $0 / 0098$ \\
Camel's thorn & $0 / 0901$ & $0 / 0627$ & $0 / 0234$ & $0 / 0185$ & $0 / 0093$ \\
Glasswort & $0 / 1803$ & $0 / 0836$ & $0 / 0468$ & $0 / 0208$ & $0 / 0116$ \\
\hline
\end{tabular}

Table 12. Agreement matrix (C)

\begin{tabular}{cccccc}
\hline Species & $\begin{array}{c}\text { Compatibility rate } \\
\text { with environment }\end{array}$ & $\begin{array}{c}\text { Plant height } \\
(\mathrm{cm})\end{array}$ & $\begin{array}{c}\text { Density in } \\
\text { hectare }\end{array}$ & $\begin{array}{c}\text { Canopy Diameter } \\
(\mathrm{cm})\end{array}$ & $\begin{array}{c}\text { Canopy Surface } \\
(\%)\end{array}$ \\
\hline Sagebrush & $0 / 0000$ & $1 / 0000$ & $1 / 0000$ & $0 / 0000$ & $1 / 0000$ \\
Artichoke & $0 / 0000$ & $0 / 0000$ & $0 / 3280$ & $0 / 0000$ & $0 / 0000$ \\
Charkha & $0 / 0000$ & $0 / 6220$ & $0 / 0000$ & $0 / 0000$ & $0 / 6720$ \\
Milk vetch & $1 / 0000$ & $1 / 0000$ & $1 / 0000$ & $0 / 0000$ & $1 / 0000$ \\
Espand & $0 / 0000$ & $1 / 0000$ & $0 / 3280$ & $0 / 0000$ & $0 / 0000$ \\
Camel's thorn & $0 / 0000$ & $0 / 1026$ & $0 / 0678$ & $0 / 0000$ & $0 / 0000$ \\
Glasswort & $0 / 0000$ & $1 / 0000$ & $0 / 3280$ & $0 / 0000$ & $0 / 6720$ \\
\hline
\end{tabular}

Table 13. Disagreement matrix (D)

\begin{tabular}{cccccc}
\hline Species & $\begin{array}{c}\text { Compatibility rate } \\
\text { with environment }\end{array}$ & $\begin{array}{c}\text { Plant height } \\
(\mathrm{cm})\end{array}$ & $\begin{array}{c}\text { Density in } \\
\text { hectare }\end{array}$ & $\begin{array}{c}\text { Canopy Diameter } \\
(\mathrm{cm})\end{array}$ & $\begin{array}{c}\text { Canopy Surface } \\
(\%)\end{array}$ \\
\hline Sagebrush & 0 & 0 & 0 & 1 & 0 \\
Artichoke & 1 & 0 & 1 & 1 & 1 \\
Charkha & 1 & $0 / 092702$ & 0 & 1 & $0 / 660503$ \\
Milk vetch & 0 & 0 & 0 & 0 & 0 \\
Espand & 1 & 0 & 1 & 1 & 0 \\
Camel's thorn & 1 & 1 & 1 & 1 & 1 \\
Glasswort & 1 & 0 & 1 & $0 / 328009$ & $0 / 695266$ \\
\hline
\end{tabular}

Table 14. Agreement dominance matrix (F)

\begin{tabular}{cccccc}
\hline Species & $\begin{array}{c}\text { Compatibility rate } \\
\text { with environment }\end{array}$ & $\begin{array}{c}\text { Plant height } \\
(\mathrm{cm})\end{array}$ & $\begin{array}{c}\text { Density in } \\
\text { hectare }\end{array}$ & $\begin{array}{c}\text { Canopy Diameter } \\
(\mathrm{cm})\end{array}$ & $\begin{array}{c}\text { Canopy Surface } \\
(\%)\end{array}$ \\
\hline Sagebrush & 0 & 1 & 1 & 0 & 1 \\
Artichoke & 0 & 0 & 1 & 0 & 0 \\
Charkha & 0 & 1 & 0 & 0 & 1 \\
Milk vetch & 1 & 1 & 1 & 0 & 1 \\
Espand & 0 & 1 & 1 & 0 & 0 \\
Camel's thorn & 0 & 0 & 0 & 0 & 0 \\
Glasswort & 0 & 1 & 1 & 0 & 1 \\
\hline
\end{tabular}


Table 15. Disagreement dominance matrix (G)

\begin{tabular}{cccccc}
\hline Species & $\begin{array}{c}\text { Compatibility rate } \\
\text { with environment }\end{array}$ & $\begin{array}{c}\text { Plant height } \\
(\mathrm{cm})\end{array}$ & $\begin{array}{c}\text { Density in } \\
\text { hectare }\end{array}$ & $\begin{array}{c}\text { Canopy Diameter } \\
(\mathrm{cm})\end{array}$ & $\begin{array}{c}\text { Canopy Surface } \\
(\%)\end{array}$ \\
\hline Sagebrush & 0 & 1 & 1 & 0 & 1 \\
Artichoke & 0 & 0 & 0 & 0 & 0 \\
Charkha & 0 & 1 & 0 & 0 & 0 \\
Milk vetch & 1 & 1 & 1 & 0 & 1 \\
Espand & 0 & 1 & 0 & 0 & 0 \\
Camel's thorn & 0 & 0 & 0 & 0 & 0 \\
Glasswort & 0 & 1 & 0 & 1 & 0 \\
\hline
\end{tabular}

Table 16. Final dominance matrix $(\mathrm{H})$

\begin{tabular}{cccccc}
\hline Species & $\begin{array}{c}\text { Compatibility rate } \\
\text { with environment }\end{array}$ & $\begin{array}{c}\text { Plant height } \\
(\mathrm{cm})\end{array}$ & $\begin{array}{c}\text { Density in } \\
\text { hectare }\end{array}$ & $\begin{array}{c}\text { Canopy Diameter } \\
(\mathrm{cm})\end{array}$ & $\begin{array}{c}\text { Canopy Surface } \\
(\%)\end{array}$ \\
\hline Sagebrush & 0 & 1 & 1 & 0 & 1 \\
Artichoke & 0 & 0 & 0 & 0 & 0 \\
Charkha & 0 & 1 & 0 & 0 & 0 \\
Milk vetch & 1 & 1 & 1 & 0 & 1 \\
Espand & 0 & 1 & 0 & 0 & 0 \\
Camel's thorn & 0 & 0 & 0 & 0 & 0 \\
Glasswort & 0 & 1 & 0 & 1 & 0 \\
\hline
\end{tabular}

Table 17. The number of dominance and defeat of each of the selected species

\begin{tabular}{cccc}
\hline Species & Number of dominances & Number of defeats & Difference \\
\hline Sagebrush & 3 & 2 & 1 \\
Artichoke & 0 & 5 & -5 \\
Charkha & 1 & 4 & -3 \\
Milk vetch & 4 & 1 & 3 \\
Espand & 1 & 4 & -3 \\
Camel's thorn & 0 & 5 & -5 \\
Glasswort & 1 & 4 & -3 \\
\hline
\end{tabular}

\section{Conclusion}

The results of the research shows that in linear assignment method, among 7 studied plant species, milk vetch species is in the first ranking with one score, and is the best species to stabilize sand in the studied area and the Camel's thorn species lies at the bottom of the ranking chart and can't be suitable for sand stabilization. Artichoke, Espand, Glasswort, Sagebrush and Charkha lie in the next rankings respectively by their importance.

In ELECTRE method, among 7 plant species studied in this research, the milk vetch species with four dominances and one defeat with 3 scores is in the first ranking and the Camel's thorn and Artichoke species with five defeats and no dominance with (-5) score lie at the bottom of the ranking. Glasswort, Charkha, Espand and Sagebrush with $(1,1,1,3)$ dominances and $(4,4,4,2)$ defeats with $(-3,-3,-3,1)$ scores respectively lie in the next ranks. It should be noticed that Artichoke, Camel's thorn, Glasswort, Charkha and Espand species must be omitted because the number of their dominances were less than the number of their defeats. The results of the linear assignment method for ranking the studied plant species for stabilizing sand dune were more compatible with reality and were more accurate and precise.

\section{References}

Ahmad, S. A., Tewfik, S. R., \& Talaa, H. A. (2002). Development and verification if a decision support system for the selection if optimum water reuse scheme. Desalination, 152, 339-352.

Ahmadi, H., \& FeinNia, S. (1999). Quaternary formations: Theoretical and applied basics in natural resources (2nd ed.) Tehran, Iran: Tehran University Press.

Alaee-Taleghani, M. (2001). Iran geomorphology. Ghoomes Publications, Tehran, Iran. 
Anand-Raj, P. A., \& Kumar, D. N. (1996). Ranking of river basin alternative using ELECTER. Hydrological Science, 41, 326-335.

Asayesh, H., \& Estelaji, A. (2003). Principles and methods of regional planning: Models, methods, and skills. Publications of Shahrerey Azad University, Tehran, Iran.

Chen, Y. W. (2001). Implementing a hierarchy process by Fuzzy integral. Inter. Journal of Fuzzy System, 3(1).

Danin, A. (1996). Plants of desert dunes. Springer Publications. http://dx.doi.org/10.1007/978-3-642-60975-6

Dougill, A. J., \& Thomas, A. D. (2002). Formation controls and their validity as indicators of soil degradation. Journal of Arid Environments, 50, 413-428. http://dx.doi.org/10.1006/jare.2001.0909

Freeze, R. A., \& Cherry, J. A. (1979). Groundwater. Prentice-Hall, Englewood Cliffs, New Jersey.

Kohansal, R., \& Hadi, R. (2008). Selection and ranking sprinkler and traditional irrigation systems in Khorasan-Razavi Province. Agricultural Science and Industries Journal, 1(2), 91-104.

Krishnomurthy, J., Kumar, N. Jayaraman, V., \& Manivel, M. (1996). An approach to demarcate ground water potential zones thorough remote sensing and a geographical information system. International Journal of Remote Sensing, 17(10), 1867-1884. http://dx.doi.org/10.1080/01431169608948744

Lancaster, N., \& Baas, A. C. W. (1998). Influence of vegetation cover on sand transport by wind: Field studies at Owens Lake, California. Earth Surface Processes and Landforms, 23, 69-82. http://dx.doi.org/10.1002/ (SICI)1096-9837(199801)23:1<69::AID-ESP823>3.0.CO;2-G

Limon, G. A., \& Martinez, Y. (2006). Multi-criteria modeling of irrigation water marked at basin level: A Spanish case study. European Journal of operational of Research, 173, 313-336.

Mianabadi, H., \& Afshar, A. (2007). Fuzzy group decision making and its application in water resource planning and management. Proceedings of Iran Water Resource Management Conference, January 12-13, 321-329.

Mianabadi, H., \& Afshar, A. (2008). Multi-attribute decision making to rank urban water supply scheme. Water and Watershed Journal, 19(66), 34-45.

Poorkhosravani, M., Vali, A., \& Moeeiri, M. (2010). Studying plant morphological relationships with morphometric characteristics of nebkhas of Tamarixmascatensis species in Kheirabad region in Sirjan. Geography and Planning Journal, 15(3).

Refahi, H. (2009). Wind erosion and its control. Tehran University Press, Tehran, Iran.

Roy, B. (1991). The outranking approach and the foundation of ELECTRE. Methods, Theory and Decision, 31, 49-73. http://dx.doi.org/10.1007/BF00134132

Saaty, T. L. (1986). Axiomatic foundation of analytical hierarchy process. Management science, 31(7).

Saaty, T. L. (1994). Highlights and critical points in the theory and application of the analytical hierarchy process. European Journal of Operational Research, 74, 426-447. http://dx.doi.org/10.1016/0377-2217(94)90222-4

Shokooee, H. (1995). New perspectives in urban geography. Samt Publications. Tehran, Iran.

Tavakoli, A., \& Ahmadi, A. (2005). The model of selecting and prioritizing technology transmission methods. Publications of Science and Industry University, Tehran, Iran.

Tille, M., \& Dumont, A. G. (2003). Methods of multi-criteria decision analysis within the road project like an element of the sustainability. Proceedings of 3rd Swiss Transport Research Conference, 19-21 March, 221-229.

Vali, A., \& Ghazavi, G. H. (2003). Studying the relationship between plant species density with the degree of salt and soil texture of the salt land in Karsiah in Darab. Desert Journal, 8(2).

Van der Stoel, C. D., Van der Putten, W. H., \& Duyts, H. (2002). Development of a negative plant-soil feedback in the expansion zone of the clonalgrass Ammophilaarenaria following root formation and nematode colonization. The Journal of Ecology, 90(6), 978-988. http://dx.doi.org/10.1046/j.1365-2745.2002.00727.x

\section{Copyrights}

Copyright for this article is retained by the author(s), with first publication rights granted to the journal.

This is an open-access article distributed under the terms and conditions of the Creative Commons Attribution license (http://creativecommons.org/licenses/by/3.0/). 